\title{
Concerns of the Periphery / Peripheral Concerns: Tempting Territories of the Balkans
}

URSULA REBER

On a thematic map, peripheries are those pale areas around a more colorful, vibrant center." The center focuses and attracts attention; it is more densely shaded, while peripheries are interspersed with white blanks, especially when the map indicates matters of civilization, culture or tourism. It is the periphery of Europe's periphery (as seen from a Eurocentrist point of view) - Dalmatia, Bosnia and Montenegro - that the following will concern and visit in the company of three different voyagers from the turn of the past century. The three texts under consideration are quite diverse in terms of genre. I will first analyze an Austrian research report in depth and contrast it to two shorter studies of a German travel guide and a Bavarian travelogue. Heinrich Daublebsky von Sterneck considers civilizational matters in his 1877 treatise Geografische Verhältnisse, Communicationen und das Reisen in Bosnien, der Herzegovina und Nord-Montenegro. Aus eigener Anschauung geschildert (Geographical Relations, Communications and Travels in Bosnia, Herzegovina and northern Montenegro, described from personal experience) in reconnoitering the best ways for building railways. Tourism was Dr. Kurt Floericke's chief concern in writing his travel story "Dalmatien und Montenegro. Blicke ins 'Kulissenland"' (Dalmatia and Montenegro, Looking Behind the Stage Curtains, 1911), and Artur Achleitner's "Reisen im slavischen Süden (Dalmatien und Montenegro)" (Travels in the Slavic South (Dalmatia and Montenegro), 1913) is dedicated to more general cultural concerns.

In order to find out these three writers' interest in this particular periphery at this particular historical juncture, some questions bear asking: What do they reveal, and what are they concealing? What investments do they have in these territories, and what are they gaining for their own identification and self-conscience when attributing certain identities to the periphery's inhabitants? What led these voyagers to write down their impressions, judgments and demarcation lines, to leave for posterity their own "imaginary cartography" of these areas? Can places of common cultural knowledge be found in their maps? Do these imaginary cartographies show streets of hegemonic interests crossing the landscape of private experiences? And, finally, is there a space that is only weakly coded and gives "the other" the possibility to speak - a space one could call "Adiáphora," in which neither good nor bad (the original meaning of the Greek 
adjective adiáphoron) and therefore equal but not singular singularities are decentred.

\section{LANDBEGEH(R)UNG: OCCUPYING DESIRABLE LAND}

Dalmatians from the very start were necessarily reliant on the sea; the long and richly structured coastline had to be brought into contact with the isolated, difficult to access hinterland, while at the same time stimulating more civilized foreigners to colonize those coastal regions and to found trading settlements there. This, in fact, was the case already in ancient times. (Floericke 7$)^{1}$

At some very basic level, imperialism means thinking about, settling on, controlling land that you do not possess, that is distant, that is lived on and owned by others. (Said 5).

It makes a great deal of sense to read Sterneck's and the other two travel accounts against the texts of Edward Said and of authors who build upon his work. According to this approach it seems to be inevitable that thinking of territories that do not belong to me but to others mechanically produces images of "the own" and "the other," and therefore of identity and difference:

Territory and possessions are at stake, geography and power. Everything about human history is rooted in the earth, which has meant that we must think about habitation, but it has also meant that people have planned to have more territory and therefore must do something about its indigenous residents (ibid.).

Apart from the essentialism of an origin beyond space and time that seems to be implicated in Said's notion of the rooting of every human history as a history of conquest and possession, it nevertheless makes the transfer to concrete differentiation of interests in foreign territories possible. "Territory," "space," "place," and "location" are, of course, by no means bound to the "real" earth; they should be understood instead as products of symbolic coding, on the one hand, and as mediated spaces of experience and communication, on the other. Thus, these terms can be delinked from the earth. What takes over the history of conquest and settling in terms of concrete colonial power is the imaginative mapping of foreign landscapes that can be settled but do not have to be. With respect to the dynamics of such mediated (and mediating) spaces, the history of changing or wandering interests and ideas can be told without being caught in the trap of identity politics ${ }^{2}$ - a danger that, for example, Doreen Massey draws attention to in arguing against common ideas of strong reciprocal connections between place, culture and identity. ${ }^{3}$

In the travel accounts under discussion here the Balkans reflect changing interests, according to the historical context of the respective author. In the first account the Balkans are constructed as a periphery that is desirable both economically and politically, in the second they are a symbol of mythical and exotic spaces, and in the third, they function as separate territories with their 
own perceptible dynamics. The earliest account and the one discussed first in this paper, is the report by Daublebsky von Sterneck. It gives clear evidence of its historical context, which was marked by the struggle over territory that eventually led to the Congress of Berlin in 1878. The main strategy of the report is to define the 'foreigners' and the 'foreign landscapes' of Dalmatia and Bosnia as archaic and exotic, a kind of pre-modernity that the Balkans has to overcome in order to catch up with the developed and modern (Austrian-Hungarian) society. In order to justify his interest in Bosnian territory, Sterneck uses the rash equating of place with culture and identity. The author describes the Dalmatian mentality as marked and dehumanized by the rough Dalmatian landscape, whereas the morality of the Bosnian regions he sees as proof their level of development (and ability to develop).

Kurt Floericke's account from 1911 does not evidence the concrete territorial interests that can be found in Daublesksky von Sterneck's. Rather, his mapping of Dalmatia and Montengro temporalizes space, ${ }^{4}$ framing contemporary Dalmatia with her great past, her Roman and Byzantine history. In the second section of the account, which deals with Montenegro, time also plays a far more important role than space for understanding the country. On the disparate time-space map of Montenegro that Floericke constructs, a wild and uncultivated landscape meets an archaic social-system scattered with technical objects of European modernity. The chronology would seem to be reversed; because Montenegro's time is archaic, newspapers, automobiles and other objects of modernity seem to be the relicts of another, past era. This heterogeneity the author commutes into a causa finalis that directly leads the country to European development, on the one hand, while on the other hand, he constitutes it as a reservation where tourists may gaze at a vanishing utopian origin. Thus, Floericke's desire for these landscapes is highly imaginative and utopian.

The final travel account was written by Artur Achleitner. It seems to make space for the voices of Montenegrins themselves by showing Montenegro's inner political, economic and aesthetic dynamics instead of simply charting archaic and exotic regions and people. This is the only text that comes near to being a possible map of "Adiáphora."

“IN THESE REGIONS I CAME INTO CLOSE CONTACT WITH HUNGER AND, WHAT IS MUCH MORE,

WITH THIRST AND FEVER":

DECAYING DALMATIA VS. TEMPTING BOSNIA

K.u.k. General Heinrich Daublebsky von Sterneck ${ }^{5}$ was ordered by the Austrian-Hungarian Ministery of War to undertake a journey through Bosnia, Herzegovina and northern Montenegro from 1871 to 1875, and to report on his findings. ${ }^{6}$ The main interests of his travels, and the report, which was published 
in 1877 , were "first of all geodesic" in nature "and could only incidentally serve other aims (Sterneck 51$)^{7}$, which included providing "observations on topics from rivers and mountains to communications, as well as on modes of traveling through these regions, on adapting the railways to the landscape, and lastly on the many old monuments to be found in the region" (8). ${ }^{8}$ The main, as well as the peripheral, aims are reflected in three maps, "to which these lines are added only as explanation" (4). ${ }^{9}$ However, behind these lines, which clearly exceed an only explanatory task one can locate veiled interests in Bosnian and Dalmatian landscapes and the economic resources in and beneath them. Sterneck's orders, experiences, and modes of perception and judgment of the "visible facts" are interrelated with each other as text and context. Through his strategies of describing and interpreting the visible, his relationship with Austrian imperialism emerges. What also emerges - when one re-embeds Sterneck's account into the historical situation, analyzes and re-connects his personal experiences with orders and professional and geopolitical involvement - is the report's similarity with colonial ways of per- and conception of landscape and natives and the way "facts" switch to a continuing production of images of the other.

Sterneck declares not once but twice that he does not intend to provide either a military sketch "or a political pamphlet," ${ }^{10}$ once near the beginning (4), and again a few pages later when outlining the structure of his report (8). Perhaps it is not that surprising that a k.k. general would not want to admit to be pursuing any military interests in a region that only one year later, in 1878 , would be under Austrian-Hungarian administration, especially given that the Balkans were being struggled over not only by the Habsburgs but also by a number of empires and nation-states, all of which had explicitly political, representational, economical, as well as hegemonic interests in the Balkans' geography. One should also remember, as Stevan Pavlowitch does, that there was an unofficial agreement between Russia and Austria-Hungary that Austria-Hungary "could [...] help herself to Bosnia and Herzegovina" if they guaranteed "an attitude of benevolent neutrality towards Russia" in the case of Russia going to war with Turkey (Pavlowitch 111). ${ }^{11}$ It is understandable that Sterneck had to be scrupulous, since he personally wanted to limit how his observations could be used or, more to the point, misused.

One should not, however, take Sterneck's declaration about the mere scientific and technological aims of his mission at face value. He later gives arguments for and against specific courses and locations where the railways could be built:

Finally, the last part of the marked-out route is of little worth. Since it is so near to the Serbian border, it would have to be constantly defended along its entire length in the case of political complications. ${ }^{12}$ 
Because of its great vulnerability and unreliability, also the military use-value of the railway would be nil, instead of being driven forward by it (43). ${ }^{13}$ Whether or not Sterneck was convinced of the non-military and therefore non-political nature of his exploratory mission makes little difference. Read together with a further declaration of neutrality - that "there [is not] any ulterior motive of conquest because the argumentation hold regardless of which colors the boundary posts are painted" $(42)^{14}$ - the entire report smacks of what Said has called "knowledge of empire," knowledge which everybody who represents an imperial form of culture has - that belonging to an empire means being dependent on the exploitation of territories and indigenous populations situated far away. Said reveals this kind of "geopolitical unconscious" in the writings of Jane Austen, a bourgeois writer who never set foot on colonial ground. In the case of Sterneck, in contrast, who was directly involved in the process of gaining new land by building communications at a time when Bosnia, Herzegovina, and Montenegro were only desired by, but by no means belonged to, the Habsburg Monarchy, such a "geopolitical consciousness" is a matter of course. Unlike Jane Austen, Sterneck was actually professionally engaged in imperialism as it is literally understood. His technological mission to countries on the periphery was to justify the already planned hegemonic broadening of the Austrian sphere of influence.

He provides these desires with not only a geographical basis but serves them also in ethnographical and cultural respects. As Pavlowitch relates, for the Habsburgs "a Balkan mission would be invented as a substitute by the aristocracy, the military and the bureaucracy [...] but it was also a way of escaping from the gradual accumulation of problems and conflicts into a foreign policy of prestige" (101).

Sterneck complies with his mission of communication(s) in the frame of imperial orders of regulation, whereby he again transgresses his own agenda "not to give a formal description of Bosnia and the Herzegovina" 15 towards "ethnographical" instead of "geographical" sketches. He personifies the landscape, renaturalizes the natives and in combination with mere geographical descriptions he homogenizes all this and presents it as a harmonious entity:

The photographs of Ljubinje and Trebinje, as well as other pictures of these regions, give the impression of the glazed-over eyes of a dying man. For miles there is no water to be found, nearly no vegetation, and the whole area is uninhabited. The great number of deserted houses clearly shows that the population is decreasing for which the political circumstances only partially can be responsible since under the same political situation in the neighboring Bosnia the contrary phenomenon can be observed. (Sterneck $13)^{16}$ 
The Dalmatia that is discussed here, and presented oro- and hydrographically in full a few pages earlier, completely dissolves into the medium of the photograph. From the author's viewpoint, this medium is capable of aptly and authentically representing his experiences of arduousness and suffering. In order to be able to reproduce and mediate these experiences and constitute "subjects" in the process, the author puts back this suffering through (or on account of) the landscape into the deserted landscape. The absence of humans underscores the truth not only of the author's own strains but also of the kind of "anthropological geography" his text offers. Even the indigenous populations are not able to survive in this region. The single photograph, described above, has the power to give a truthful impression of the overall dreariness of the landscape, as well as the grief inherent in civilization. Moreover, it testifies to the desolate state of a population which, given its surroundings, "is facing desperate perspectives and unstoppably heading toward decay" and "may even disappear completely" (12). ${ }^{17}$ These apocalyptic perspectives lead to the statement "that from a (national) economic point of view, it is useless to build ports or railways in these areas" (13). ${ }^{18}$ Neither is a change in the "political situation" a potential remedy, something closely connected to the development of communications as will be seen later. Thus, in typical colonial fashion, ethnography and cultural argumentation go hand in hand in Sterneck's text to economically exclude the indigenous populations from resources like railways. The author's strategies for describing these territories via texts, maps and photography, which he praises for its documentary, exemplary and authentic character (4), result in a task of doubly representing landscapes, calling to mind Andrew Sluyter's Colonialism and Landscape:

Land is certainly an appropriate and adequate category to dignify the environment that natives and Europeans struggle over: the resources such as soil, vegetation, animals, minerals and water. Yet more than simply control over environment, the struggle revolves around control over space, over territories - over landscapes. [...] At the same time as being an object of control, however, space is a medium through which the struggle for control takes place, the spatial strategies of domination and resistance [...]. [...] landscape thus is doubly essential, to indicate both conflict over space and conflict through space. (Sluyter 9)

The objective perception and the subjectively connoted impression of the landscape are equated with the imperial interests in the territory by means of metaphors. Regarding the crown-land Dalmatia, which already belonged to the Austrian sphere of influence, Sterneck approved of the building of railways only if they connected Dalmatia with Bosnia, whereas he clearly rejected the markedout route along the coast as it would not be of any use "in military [!] or political respects" (13). ${ }^{19}$ Also serving this equating and homogenizing aim is the way Sterneck naturalizes the indigenous populations, ${ }^{20}$ whom he treats as a mere 
part of nature and never as an independent factor throughout the text, and who are dying together with nature, making potential profit even more unlikely.

Dalmatia's neighbor Bosnia, on the other hand, is revealed by Sterneck to be the true territory of hegemonic imperial interests. In contrast to desert-like Dalmatia, which had been rendered such by Venetian greed, "marvelous primeval forests" grew in many parts of Bosnia. He presents it as a lovely, fruitfilled landscape that "is quite well cultivated at present" and populated "by more industrious indigenous populations."21 The choice of elativs and comparatives nevertheless gives a clear signal that both, land and people, are worth further cultivation and civilization:

If this population is currently at a low level of civilization, deteriorating sometimes to stupidity, the causes responsible for this are situations which under other circumstances would drive the Bosnian and Montenegrin people - countries that both are very poor and void of any resources - to the spirit of independence and the desire for fighting. $(15)^{22}$

As before, the circumstances to which Sterneck is referring are political ones. In Bosnia's case, he refers to the Ottoman rule, against which the Montenegrins, unlike the Bosnians, had always fought successfully, according to the author and to a popular stereotype. ${ }^{23}$ Thus, a spirit of independence and pugnacity characterized the Montenegrins, whereas foreign rule had led the Bosnians only to "servility" (16).

In Sterneck's argument for building a railway connecting Dalmatia with Bosnia, the imperial interest in a useful unity of territory and population clearly emerges. Bosnia is Austrian Dalmatia's hinterland and is necessary for the trade and transport of merchandise to the coast from the eastern crown-lands. The reason why the author in turn treats Bosnia's natives strategically as part of nature, as some kind of "fauna," is connected to the special argument of "Culturrücksichten." The civilizational tasks of the railway that Sterneck had carefully prepared in the first part of his report can be described as enlightening effects. The German word "Aufklärung" that is used here, has the twofold and maybe intended - meaning of developing land, as well as social enlightenment. Therefore, building the railway also means that the Bosnians will have the possibility to get their share of welfare that in turn will have the positive effect of bringing "the current blazing fights about oppression, freedom and independence, and reduction of the heavy tax burden" to an end: ${ }^{24}$

Under the present circumstances, diplomacy will never put an end to these fights - and the sword only after hecatombs of victims, in fact only by extinguishing the entire subjugated race (39). ${ }^{25}$

Keeping in mind that for Sterneck the Bosnians are "deteriorating to stupidity sometimes," it seems obvious that it is them he is talking about when he refers to what Said calls a "subject race," meaning one that is subjugated, objectified or 
disciplined. On the other hand - returning to the meanings of "enlightenment" - he seems to take for granted that new settlements along the route, as well as an improvement in hygiene, will be secondary benefits of the technological enlightenment. Both effects can already be found, of course, in the well-ordered capitalist circumstances of Austria-Hungary herself, under which "those who are industrious gain property and prestige, and therefore only those who are industrious and intelligent gain power, which also solves the religion issue" (ibid.). ${ }^{26}$

This example introduces and evokes the "myth of Europe." The Bosnians can be seen as a typical example of a subject race. With regard to the Muslim faith and the Ottoman-Turkish rule over the country, Bosnia is - literally - a "province of the Orientalist." ${ }^{27}$ Austria was offering to free a country from Ottoman (and especially Muslim) rule, that is, from orientalization, the symptoms of which were "greed and a servile mind." In Sterneck's view, Bosnia had already succumbed to the contagion of the oriental illness. The unhygienic circumstances he describes in full in the first paragraphs, that materially consist of worms, leeches, insects, and polluted water, are the visible manifestations of this so-called oriental illness, since the Orient is traditionally characterized, firstly, by a far too unrestrained fertility and, secondly, by a laxity in hygienic matters. The danger of contagion is felt by the traveler, who himself becomes lax, weary and stupid. ${ }^{28}$ The contrast of the Balkans people to the rest of Europe with respect to their way of life and Weltanschauung was spurred on by Muslim rule. Thus, increasing the sphere of enlightened and civilized Christian European ${ }^{29}$ influence meant developing, liberating, and re-christianizing these areas. The Balkans were not as foreign to Europe as they seemed, since they geographically and traditionally belong to Europe. On the contrary, it is the Ottoman culture and the Muslim faith that are imported, foreign elements, so that re-christianization logically seems to offer a proper ethnic and religious solution. Austrian-Hungarian occupation of Bosnia-Herzegovina was proposed at the Congress of Berlin on July 28, 1878:

The Government of Austria-Hungary, not desiring to undertake the administration of the Sanjak of Novibazar, which extends between Serbia and Montenegro in a southeasterly direction to the other side of Mitrovitza, the Ottoman Government will continue to exercise its functions there. Nevertheless, in order to assure the maintenance of the new political state of affairs, as well as freedom and security of communications, AustriaHungary reserves the right to keep garrisons and have military and commercial roads in the whole of this part of the ancient Vilayet of Bosnia. To this end the Governments of Austria-Hungary and Turkey reserve to themselves to come to an understanding on the details. (Article 25 of the "Treaty of Berlin") ) $^{30}$

On the surface, Article 25 had little to do with undoing Turkish-Ottoman "orientalization," but rather with keeping Serbian and Montenegrin agitations away from this region and therefore hindering the desired unification of the "South- 
ern Slavs." It was to this end that Austria and Turkey entered into this alliance. A few years earlier, Sterneck had had to search for good reasons beyond the main economic motivation for Austrian-Hungarian activities in these territories, and the "blazing fights" between Christians and Muslims easily and directly led to the idea of an "oriental gap." If one looks at the argumentation of Count Andrassy (1823-1890), foreign minister of the Dual Monarchy who represented Austria-Hungary at the Congress of Berlin, as displayed in a letter of December 30, 1875, when he repeatedly accuses the Porte of despotism and fraud apart from "facts" such as that the promises of equating both religions weren't realized - one finds that he used key words indicative of orientalist knowledge. Despotism is characterized as oriental and never western:

One of the principal causes of this mistrust [against Ottoman laws] is in the fact that more than one measure announced in the Sultan's latest rescripts has already been announced in former Hatti-Chérifs, without causing any appreciable amelioration of the lot of the Christians. ${ }^{31}$

Andrassy's and Sterneck's strategies of argumentation draw the same imagined geography of Ottoman Bosnia. The difference is that in the case of the Hungarian minister, the oriental illness has political connotations, whereas in the view and experience of Sterneck's one-man-expedition it offends his body.

This oriental despotism is also injurious to the Bosnians who belong to the "body" of Europe. Sterneck's main focus is on the remedy for civilization that is capitalization, and his final argument is: "that at present human labor, as well as ground for building the railway, is sold very cheaply" (40). ${ }^{32}$ Both human labor and land would come in handy for the imperialist Habsburg monarchy, not for the Bosnians themselves. ${ }^{33}$ Sterneck is well aware of this fact since he feels obliged to exclude any motive of conquest and to refer instead to humanitarian motives. He even feels forced to appeal to Dalmatian patriotism. But Dalmatians are not Sterneck's addressee; rather he re-presents them in the posture of a proven and intimate expert on Balkan matters. Sterneck thus legitimates his position, establishing that he is entitled to give the Balkans a voice in the Austrian-Hungarian military, diplomacy, and bureaucracy.

The cartography of Dalmatia and Bosnia Sterneck sketches out crosses the borders of mere geodesics, geography and matters of communications. Excerpts of his diary together with ethnographic reflections constitute a "cultural geography" that is particularly marked by two linked points: the fading out of the landscape already cultivated by the indigenous populations, and the passivity of the naturalized indigenous populations, a phenomenon typical of colonial landscapes as Andrew Sluyter has pointed out. The deserted, apocalyptic landscape Sterneck evokes is resistant to any amateurish attempt to civilize it and is represented by badly surfaced streets, bridges that were never finished or are already caved in, etc. The indigenous populations deal with this weakly cultivated land- 
scape in a strange manner: they don't use the few streets there are but rather prefer small and rough tracks besides them; they settle down anywhere without any consideration of trade-ways. In other words, their mentality is adapted to the landscape. Both are considered as a unity, as two sides of a coin, and therefore the indigenous populations are less worth mentioning than their far more admirable horses, to whom Sterneck feels is due "an act of guilt-induced thankfulness... when I recall the reason of those animals" (24). ${ }^{34}$

For Sterneck, the indigenous populations are not mute because of difficulties communicating between different languages; rather they are part of nature, which is mute, and so they have to keep silent as well. As a traveler, he feels he has to rely, for example, on a Turkish gendarme who is approximately equal in rank and has the power and the right to give information. The indigenous population as subject is visible only against the background of imperialist-colonialist identification, this curious "negative dialectics of recognition":

The colonizing produces the colonialized as negation but with the aid of dialectics this negative colonialized identity again is negated in order to establish the positive identity of the colonizer (Hardt and Negri 141).

In the Balkans of the nineteenth and twentieth centuries, these colonial mechanisms of producing identity and otherness redoubled, as well as splitting up, since the 'subject races' also belonged geographically and culturally to Europe (mind that their common history with European Venice, for example, is also an imperialist one). The Balkan Europeans had already been subjected by another, "orientalist" power. Due to the contagion of the "oriental illness," these peoples were orientalized by the Ottoman powers and had to be "healed," for example with the help of civilizatory communications that reconnected them to the "heart" of Europe. Only with respect to something like "race" did they differ from Europe. They were "Slavs," ${ }^{35}$ whose attempts to unite were feared and fought by European 'non-Slavs' in order to prevent a pan-Slavic growth of power. Insofar two imaginations - one that they were peoples of another part of the world, "heavily deteriorated compared with earlier greatness and power"36 and that they were brothers, who must be freed from the Orient and re-integrated into Europe - were erratically and unalterable put beside each other. ${ }^{37}$ Thinking of territories and landscapes causes an imperialist desire due to profession, class and gender, that is claiming the aesthetic and the useable (Bosnia's fruitful regions) for itself, whereas the ugly and useless (desert-like Dalmatia) is left to the other. ${ }^{38}$

In the question of what should happen to the landowners under Austrian rule Sterneck is also divided as he sees at least two kinds of owners: the Ottoman possessors and the native Bosnians. Of course the situation was much more complicated in the nineteenth century. ${ }^{39}$ Since he wants the Ottoman possessors to be substituted, the well-functioning arrangement with them has to 
be superseded by the production of alterity that serves 'his' own positive identification. ${ }^{40}$ As long as Sterneck is a traveler, the Turkish gendarme's despot-like oriental power is useful, since the traveler needs his help for communication, organization and protection (26). The degrading re-evaluation of the Turk can only be read between the lines in if-clauses, such as "his demands even if they were unjust don't stay unfulfilled,"41 which - produce a cautious distance. Obviously, the dubious but nevertheless ubiquitous "political state" lurking behind Bosnian servility as well as behind Montenegrin pugnacity refuses complete loyalty to the Turks. It also opens up a niche for Sterneck's benevolence for the proud and independent Montenegrin or for the industrious Bosnian (as for his intelligent and patient horses). Using this niche can in principle alter the difference between peripherality and adiáphora.

\section{“BEHIND SCENIC CURTAINS": \\ PRODUCING A TOURISTIC LANDSCAPE}

Kurt Floericke's (1869-1934) 1911 Blicke ins Kulissenland is basically a tourist guide. The territorial conscience of "spaces of leisure" or "adventure" have geoaesthetic ${ }^{42}$ rather than geo-political connotations and thus the potential to get closer to an adiaphoric geography than Sterneck's imperial geography. The "land of scenery" (Floericke, title) presents a strategy of traveling that needs a stage, as well as touristic productions of landscape. As they are described by the German Floericke, Dalmatia and Montenegro work as scenery in various ways. First is their historical scenery. To know a country's history quite well is thought to make "for the best preparation for traveling." This knowledge makes the scenery "endlessly rich," as well as "dramatic and full of changes" (Floericke 7 ) $^{43}$ as though it were an operetta plot. This mnemonic theater ${ }^{44}$ tells the fantastic tale of the "splendor-loving Orientalist despot Diocletian" (6), Diocletian actually being a Roman emperor from what is today Dalmatia. It stages the tragedy of Dalmatia's colonialist history (7) from ancient to modern times, producing something "that even the wildest imagination couldn't match in its colorfulness and action!" (ibid.). ${ }^{45}$ By re-drawing historical conquests and seizing possession of territories, and by re-iterating the terms of their space-time dimensions, the links between desiring and taking space and territory into possession are not only repeated but also essentialized:

[Metaphors] are instrumental to knowledge creation and in fact may become the theory or idea they are intended to explain. [...] And metaphors are not randomly chosen. They reflect the struggle for dominance via social and cultural norms; they actively shape a world-view (Cosgrove and Domosh 30).

Floericke's dramatic metaphors of landscapes force us to imagine Dalmatia and Montenegro as spaces of specialized knowledge of Balkans history. ${ }^{46}$ Optically the native Montenegrin protagonists fit perfectly into the scenery. They are "tall, 
belligerent figures, dressed in their picturesque national costumes" (Floericke 153), while the Dalmatian "seems to be a weakling to us, whereas the Herzegovines and the Bosniaks look like exemplars of a deteriorated race in comparison with these giants of men." ${ }^{47}$ The plot of Montenegrin history has the radiance and splendor of century-long bloody partisan fighting, which, set against a precipitous landscape and harsh climate, produced "mountain Spartans in the romantic aura of brigands" (ibid.). ${ }^{48}$ The way Floericke constitutes his subject takes place exclusively in categories of aesthetics: staring at the foreigners full of admiration, narrating adventurous stories, and consequently constructing moral, temporal and spatial differences, of which the most important elements are blood revenge and strict morality. Overcoming modernity he symbolizes through the notion that liberality is realized by the strictest regime of the patriarchal king, whereas Montenegro's capital Cetinje seems to be "already a little infected by civilization" (155). ${ }^{49}$

In Floericke's travelogue, the Montenegrin doesn't keep his silence the way Sterneck's Bosnian does. Dramatic dialogues are assigned to him; however, they do not consist of speaking but of dance-like motions appropriate to an operetta. Relying on his knowledge of its history, nationality and political situation, Floericke inscribes "the other" of the Orient into an imaginary geography of aesthetic and moral imaginations of pureness, that in turn is able to confirm his own European, Christian and national identification. Morally this imagined geography transposes an archaic origin to the present time. The lived-in landscape is de-historicized, for example, when the Albanian rebellion, including the Montenegrin involvement, ${ }^{50}$ is rendered in the single picture of Albanian Harlequin costumes. Turned into mere aesthetics, they make the Balkans' imagined geography even more lively and colorful. This entire fabulous and dramatic time-space and geography is projected only to facilitate the constitution of the traveling Bavarian subject. It is only for his delight and catharsis that this heroic, as well as horrible, play is being performed on a Balkan stage. The Balkans are constituted as a landscape of desire and appropriation more obviously than in Sterneck's report. The indigenous population themselves do not narrate; rather, what we get is a tamed, stage-managed version of typical European and Christian nation-building, in which the Montenegrin is good only for the successful identification process of the observer.

“IN CETINJE MILITARY CAPS AND COATS WERE EXOTIC AND ATTRACTED ATTENTION, CAUGHT PEOPLE'S EYES": APPROXIMATING A MAP OF ADIÁPHORA

The Bavarian writer Artur Achleitner (1858-1927) traveled in the same regions as Floericke with the same intention to constitute a community between those describing and that being described, but under difference auspices. Achleinter 
was an established expert in questions of human concerns and humanity and used as his main strategy the quoting of other texts to further his cause. In the very first lines Achleitner speaks as Montenegro's advocate:

Up into the European country that is slandered the most! It is easy to climb up there; what's difficult on this interesting journey is to vanquish all of the prejudices and resentment, the hateful attempts to influence travelers, which are almost impossible to escape once the intention of the voyage has become known. Bad feeling against Montenegro in surprisingly great variety emerges. This interesting and poor country is reviled by people nobody would ever think capable of any meanness. Curiously enough the worst slanderers live quite far away from the country itself. One would expect to find jealousy and resentment in the neighboring areas, but this is not the case. (Achleitner 126) ${ }^{51}$

Writing to defend Montenegro against the Austrian resentment and hatred provoked by Austrian and Montenegrin territorial conflicts over the Albanian city of Scutari (Shkodër), ${ }^{52}$ Achleitner structured his travelogue like a cross-examination. Austrian journalists are subject to interrogation, while the central meeting with King Nicholas is formed into an ad hominem argument in order to show the grandeur and kind-heartedness as well as high cultural state of entire Montenegro as represented by its king. Not only does the king speak in this passage, his part of the dialogue is even longer than that of the narrator. The representative of the natives gets an inner-textual voice, and one that is not directed by a unchangeable script. Thus, the country's voice (although not the one of any of its inhabitants other than its ruler) can be heard throughout Achleitner's travelogue. The author employs his aesthetic and rhetorical capabilities in such a way that a space is left for other voices besides his own appeals and emotive words. Whether pointing out the dubious role in Montenegrin politics of alliances or of foreign policies that understandably enraged its Albanian or Serbian neighbors, or relating the difficulties of domestic policies, such as unemployment and the "homelessness" of young academics, the narrator never forgets to attend to the problems of either the landscape or its inhabitants. Although he does not always share the opinions he relates, he is sensitive to the connections and dynamics of education, unemployment and poverty, of dissatisfaction and rebellion. Furthermore, the narrator not only attacks journalists' disparaging remarks about Montenegro and its king, but also the colonial and romanticist production of otherness, in particular when another writer plays with the trope of transfiguring the beauty of a poor woman, a strategy which recalls Christian legends and fairy tales. These narrating and ideologizing strategies contrast with the recurring reality and incomprehensibility of bodies that are marked by poverty and privation (Achleitner 186) in a way that comes near to Said's contrapuntal reading-lessons. Achleitner's map of Montenegro does not serve as a "space of identification" either for the sake of the mapped native 
or of the reporter, since he subtly refuses the colonial machinery of producing differences and otherness as well as the imperial consciousness the writer-aesthete abdicates in order to stay in the present. That means he gives an account to the orientalist, as well as anti-orientalist discourse in a way that their mechanisms become obvious. The discursive misjudging of "land, owned by others" (Said 5) is revealed when Achleitner insists on referring to economic conflicts of power and interests that have left their marks on Montenegro's geography, when he 'gives back' the indigenous populations their independent subject-status as a civil(ized) society in opposition to the naturalness of the landscape, and when he chooses the role that alone permits humanity without identification: to be a guest. This role induces the author to risk taking on the perspective of the other. He switches the viewpoints of European observer and observed exotic, gazing on himself through the other's eyes, noticing the exoticism of his uniform that signifies a foreign way of official life.

It is true that Montenegro did not hire the narrator to be its advocate - at best he is a kind of lawyer. And it is also true that he is not completely free of any desire for the landscape. His hopes for adventure, when crossing the Montenegrin border, are unfortunately denied; and his hopes for rich personal experiences and the heightening of his prestige in his own cultural space being at the expense of others belonging to the sphere of their "own" (e.g. the translators of Nicholas's epics and lyrics) does not prevent that prestige from transferring to a certain extent to the Montenegrins.

Achleitner's kinds of identification differ notably from the more violent kinds of his two "predecessors", Sterneck and Floericke, since they don't depend on the exact opposition of self and other. Thus, the cartography of Montenegro to emerge on the eve of the First World War does not refer to an adiaphoric region void of special desires and the production of (moral) values, but comes closer to peripheral concerns, since Achleitner gives Montenegro its own timespace back. Thus, Montenegro is literally re-established as Europe's periphery interacting with its others.

\section{REFERENCES}

Cosgrove, Denis and Mona Domosh. "Author and Authority. Writing the New Cultural Geography." Place/Culture/Representation. 25-38.

Destani, Beitullah (ed.). Montenegro. Political and Ethnic Boundaries 1840-1920. 2 vols. Slough: Archive Ed., 2001.

Fischer, Wladimir. "Serbian Culture at a Twofold Periphery in the $18^{\text {th }}$ Century." Études Balkaniques 2000.2: 21-30. 
Hardt, Michael, and Antonio Negri. Empire. Die neue Weltordnung. Trans. Thomas Atzert and Andreas Wirthensohn. Frankfurt, New York: Campus, 2002.

Jameson, Fredric. Postmodernism, or, The Cultural Logic of Late Capitalism. Durham: Duke UP, 1990.

Lutter, Christina, and Markus Reisenleitner. "Post/Colonial” und / oder 'Cultural Studies'? Oder: 'Ist diese Frage überhaupt wichtig?”.... http://www.kakanien.ac.at/beitr/ theorie/CLutter MReisenleitner1, 8f.

Santifaller, Leo, und Eva Obermayer-Marnach, eds. Österreichisches Biographisches Lexikon. Bd. 1. Graz, Köln: Hermann Böhlaus Nachfahren, 1954.

Massey, Doreen. "Philosophy and Politics of Spatiality: Some Considerations." Power-Geometries and the Politics of Space-Time. Hettner Lecture 1998. Heidelberg, 1999. 27-42.

McGowan, Bruce. "The Age of the Ayans. 1699-1812." An Economic and Social History of the Ottoman Empire. Eds. Halil Inalcık and Donald Quataert. 2 ed. Vol. 2. Cambridge: Cambridge University Press, 1997. 637-758.

Müller-Funk, Wolfgang. Die Kultur und ihre Narrative. Vienna: Springer, 2001.

Pavlowitch, Stevan K. A History of the Balkans 1904-1945. London, New York: Longman, 1999.

Place/Culture/Representation. Eds. James Duncan and David Ley. London, New York: Routledge, 1993.

Quataert, Donald. "The Age of Reforms, 1812-1914." An Economic and Social History of the Ottoman Empire. Eds. Halil Inalc1k and Donald Quataert. 2 ed. Vol. 2. Cambridge: Cambridge University Press, 1997. 759-944.

Reisenleitner, Markus. "Central European Culture in Search of a Theory, or: the Lure of 'Post/colonial Studies." Spaces of Identity 2.2 (2002). http://www.spacesofidentity.net

- " "Tradition, Cultural Boundaries and the Construction of Spaces of Identity." Spaces of Identity 1.1 (2001). http://www.spacesofidentity.net

Ries, Marc. Medienkulturen. Vienna: Sonderzahl, 2002.

Said, Edward. Orientalism. Western Conceptions of the Orient. Harmondsworth: Penguin, 1995 (1978).

Sluyter, Andrew. Colonialism and Landscape. Postcolonial Theory and Applications. Lanham, Boulder, New York, Oxford: Rowman \& Littlefield, 2002.

Smith, Jonathan. "The Lie That Blinds. Destabilizing the Text of Landscape." Place/Culture/ Representation. 78-92.

Südslavische Pläne. Denkschrift über die gegenwärtige Bewegung in der Herzegowina, Bosnien, Montenegro, nebst Schilderung der historischen, politischen, socialen, religiösen und militärischen Zustände dieser Länder. Vienna, 1861.

Todorova, Maria. Imagining the Balkans. Oxford: Oxford UP, 1997.

Treadway, John D. The Falcon \& the Eagle. Montenegro and Austria-Hungary, 1908-1914. West Lafayette: Purdue UP, 1983.

\section{ENDNOTES}

* The author would like to thank Susan Ingram for helping to transpose this article, which was originally written in German, into English.

'“Die langgestreckte und reich gegliederte Küste mußte im Verein mit der Abgeschlossenheit und schweren Zugänglichkeit des Hinterlandes die Bewohner Dalmatiens von vornherein auf eine Tätigkeit zur See verweisen, mußte andrerseits auch höher kultivierte fremde Völker zur 
Kolonisierung dieser Küsten und zur Gründung von Handelsniederlassungen anreizen. Dies war denn auch schon im grauen Altertum der Fall."

${ }^{2}$ See the recent summations of Reisenleitner.

${ }^{3}$ See Massey, esp. 36, and Lutter and Reisenleitner, 8 f.

${ }^{4}$ For concepts of time-space and space-time, see Massey.

${ }^{5}$ Heinrich Daublebsky v. Sterneck belongs to a familiy of great and successful military careers. See for example Moritz Daublebsky v. Sterneck (1834-1917) who fought against Dalmatian revoltees in 1869, and the even more famous physician Robert Daublebsky v. Sterneck (1862-1906) who was involved in surveys of Turkish, Bulgarian and Servian territories. See Obermeyer-Marnach, 171.

${ }^{6}$ These dates were found on www.dinnes.net/grosse/Mostar/Mostaro2.htm.

7 "Ueberdies waren waren [...] in erster Linie geodätische Arbeiten das Ziel und nur nebenbei konnte ich anderen Zwecken dienen."

8 "Beobachtungen, sich auf Flüsse, Gebirge, Communicationen, sowie auf das Reisen in jenen Gebieten, die dem Lande anzupassenden Eisenbahnen und endlich auf die vielfach vorkommenden alten Baudenkmale erstreckend."

$9_{9}$ “[,,W] $\mathrm{Wlchen}$ diese Zeilen nur als erklärender Text beigegeben sind."

10 "[E]bensowenig eine Flugschrift mit politischen Tendenzen."

${ }^{11}$ No source for these sentences can be found in Pavlowitch.

${ }_{12}$ That the "Slav" problem was well known at the time is shown, for example, by Südslavische Pläne (Vienna, 1861).

${ }_{3}$ "Der letzte Theil der Trace endlich ist wegen [...] der Nähe der serbischen Grenze, welche im Falle politischer Verwicklungen eine unausgesetzte Vertheidigung der ganzen Linie bedingt, wegen der leichten Verletzbarkeit und der daraus resultirenden Unzuverlässigkeit der Bahn auch in militärischer Beziehung, von welcher sie wohl zumeist protegirt wird, nicht von bedeutendem Werthe..."

${ }_{14}$ "[D]a [liegt] nicht der Hintergedanke einer Eroberung, denn die Argumentation bleibt richtig, mögen die Grenzpfähle des Landes was immer für Farben tragen.” These colors could signify Serbia, Montenegro, the Ottoman Empire or Austria-Hungary.

${ }_{15}$ "[N]icht eine förmliche Beschreibung Bosniens und der Herzegovina."

16 "Die Fotografien von Ljubinje und Trebinje und andere Bilder aus jenen Gegenden machen den Eindruck der todesstarren Augen eines Verscheidenden; meilenweite Strecken sind ohne Wasser, beinahe ohne Vegetation und unbewohnt. Die vielen verlassenen Wohnsitze zeigen deutlich, dass die Zahl der Bevölkerung in Abnahme begriffen ist, woran wohl nur zum Theile die politischen Verhältnisse Schuld sind, da in dem benachbarten Bosnien unter gleichen politischen Verhältnissen das Gegentheil stattfindet."

${ }_{17}$ "Das Land geht offenbar einer traurigen Perspective und unaufhaltsam dem Verfalle entgegen [...], um vielleicht einmal ganz zu verschwinden."

${ }_{18}$ "Sie [die Lage und Beschaffenheit der Trace] lehrt, dass es, vom national-ökonomischen Standpunkte aus beurtheilt, vergebens ist, in diesem Gebiete Häfen oder Bahnen zu bauen."

${ }^{19}$ Bahnen, "von denen nicht einmal in politischer oder militärischer [!] Beziehung ein Nutzen erwartet werden darf."

20 "[A] geographic theory of colonialism and landscape [c]learly [...] must address colonial landscape transformations as seminal to current social/environmental challenges rather than as esoteric history. It must treat material/conceptual transformation as a unified process to understand how landscape acts as a 'visual vehicle of subtle and gradual inculcation [...] to make what is patently cultural appear as if it were natural' (Duncan 1990, 19). And it must encompass the social/biophysical processes, particularly those involved in human-vegetation 
interactions, that seem to be so critical to the material-conceptual feedbacks that naturalize and obscure non-urban landscape transformations" (Sluyter 9).

${ }_{21}$ "[J]etzt schon ziemlich gut bebaut"; "betriebsamere[n] Bevölkerung."

${ }_{22}$ "[W]enn sie [die Bevölkerung, Ergänzung der Verfasserin] jetzt auf einer niedrigen Culturstufe steht, stellenweise in Stumpfsinn verfällt, so sind hieran [...] Ursachen [schuld], die unter anderen Verhältnissen bei der Bevölkerung der armen und ressourcenlosen Herzegovina und Montenegro's den Geist der Selbstständigkeit und der Kampflust erzeugen."

${ }^{23}$ Cf. Südslavische Pläne 29.

${ }^{24}$ These blazing fights arose especially due to religious disparities: Christians fought against Muslims and vice versa. Further, reforms in the Ottoman rule equating religions did not take place in the planned way and led to various insurrections. In Bosnia in particular, the Turkish nobility stood against the overwhelming majority of Christian peasants, who were dependent sharecroppers who had to pay high taxes. See Pavlowitch 101ff. - See also Count Andrássy to Count Beust, December 30, 1875. (Communicated to the Earl of Derby by Count Beust, January 3). In: www.mtholyoke.edu/acad/intrel/andrassy.htm: "But, whilst legally obligatory, this principle is not yet generally applied throughout the Empire. As a matter of fact, the evidence of Christians against Mussulmans is received by the tribunals of Constantinople, and the majority of the large towns, but in some distant provinces, such as Herzegovina and Bosnia, the judges refuse to recognize its validity. It would be important then to take practical steps to relieve the Christians in future from the fear of a denial of justice." Another point of injustice were the seemingly high degree of the taxes: "One of the causes which still further materially aggravate the burden, already so heavy, of the taxes in Bosnia and the Herzegovina, is that the inhabitants believe themselves to be overburdened financially for the benefit of the capital. They entertain the belief that the proceeds of the taxes are not devoted to meeting the necessities of the province, but that the total of the sum received is immediately sent to Constantinople for the use of the Central Government. It would then be necessary to alleviate morally the weight of the burdens the province has to support, by securing that, without any encroachment on that which the expenses of the Empire require, a portion of the product of the taxes paid by the province may be reserved for purposes beneficial to its peculiar interests." (ibid.)

${ }_{25}$ "Unter den jetzigen Verhältnissen wird ihn die Diplomatie wohl niemals, das Schwert nur nach Hekatomben von Menschenopfern, - eigentlich nur durch die Ausrottung der unterliegenden Race beenden."

26 "[D]er Fleissige kommt zu Besitz und damit zur Geltung und nur dadurch, dass [...] Fleiss und Intelligenz zur Macht gelangen, wird auch die Religionsfrage gelöst werden [kann]."

${ }^{27}$ The Ottoman Empire was considered to be a kind of transitory region and space between East and West or as semi-oriental. For the overseen continuities of Balkan-Ottoman history, see Todorova, esp. 162ff. and Fischer, esp. 22f.

${ }^{28}$ See Hardt and Negri 147-149.

${ }^{29}$ Austria-Hungary rivaled other European powers in the struggle for influence in the Balkans: Italy whose argumentation was historical, and France, Germany and Russia, who supported pan-Slavism.

${ }^{30}$ Found on: www.mtholyoke.edu/acad/intrel/boshtml/bos128.htm.

${ }^{31}$ Found on: www.mtholyoke.edu/acad/intrel/andrassy.htm.

${ }_{32}$ "Wenn ich erwähne, dass jetzt Arbeitskraft und der Grund für den Bahnbau sehr billig zu haben wären, so geschieht dies ebenso im Interesse des Bahnbaues als der Bewohner des Landes, von denen Tausende in den nächsten Jahren dem Hungertode entgegengehen werden."

${ }^{33}$ With respect to the connections between enlightment, capitalism, colonialism and slavery see Hardt and Negri 133-137, Jameson, and Sluyter 14ff.

34 "Es ist ein Akt schuldiger Dankbarkeit, wenn ich hier des Verstandes dieser Thiere gedenke." 
35 'Slavs' are at best defined as a linguistic community. The definition of "Slavdom" gains elements of "race" only in the pan-Slavic movement, where being a Slav meant inherently belonging not only to community building but also to the constitution of identity. Thus, when speaking of a Slavic "race," I am not invoking the ordinary imperialist or colonialist discourse but rather refer to this sort of identity discourse. - For these difficulties in correctly understanding and describing imagined identities, I would like to thank Wladimir Fischer, who gave me a great deal of useful and highly valuable information.

${ }_{36}$ "[V]on einstiger Größe arg herab gekommenen." This is from Immanuel Kant's Physische Geographie, photocopies of different scripts of his students; here Greeks and Italians are meant.

${ }^{37}$ See Said 86: "To restore a region from its present barbarism to its former classical greatness; to instruct (for its own benefit) the Orient in the ways of the modern West."

${ }^{38}$ See Smith.

${ }^{39}$ See Bruce McGowan, "The Age of the Ayans. 1699-1812," An Economic and Social History of the Ottoman Empire, eds. Halil Inalc1k and Donald Quataert, 2 ed., vol. 2 (Cambridge: Cambridge University Press, 1997), Donald Quataert, “The Age of Reforms, 1812-1914," An Economic and Social History of the Ottoman Empire, eds. Halil Inalcık and Donald Quataert, 2 ed., vol. 2 (Cambridge: Cambridge University Press, 1997).

${ }^{40}$ Reading the documents and protocols of the European Congress at Berlin collected by Destani, the uncertainties of borders, landowners and identities become very obvious. The task of restructuring the Balkans, especially the Montenegrin borders, resulted in a variety of differing maps. The quarrels about the "real" names of islands and regions clearly shows the imperial interests motivating them. The Ottomans who were facing only a loss of territory and prestige were not only losing control over their territories but were marked as false and fraudful partners whom the Great Powers were right to mistrust. Even in such official documents, the above mentioned substitution of reciprocal arrangements can be seen. See Destani, vol. 1, $511 \mathrm{ff}$.

${ }_{41}$ "[D]ie Gendarmen [geniessen] ein unbegrenztes Ansehen, keine ihrer Forderungen und wäre sie selbst ungerecht, bleibt unerfüllt."

${ }^{42}$ As in Marc Ries's habilitation project on "geoaesthetics," this term includes social, political, as well as mere aesthetic elements of the perception of space.

43 "Überhaupt halte ich die vorherige Beschäftigung mit der Geschichte eines Landes für die beste Reisevorbereitung."; "Und wie unendlich reich, wie dramatisch und wechselvoll ist gerade die Geschichte des Kulissenlandes Dalmatien."

${ }^{44}$ See Said 21995 71f.

${ }_{45}$ "[Wi]e es auch die kühnste Phantasie nicht bunter und bewegter ersinnen könnte!"

${ }^{46}$ See Said 21995 66-68, 86-92.

${ }_{47}$ "[Hochgewachsene, kriegerische Gestalten in ihrer malerischen Nationaltracht", denen gegenüber der Dalmatiner "uns wie ein Schwächling vor[kommt], und der Herzegovce und Bosniake vollends uns diesen Hünengestalten gegenüber geradezu wie der Vertreter einer degenerierten Rasse an[mutet]".

48 "Gebirgsspartaner mit einem Hauche köstlicher Räuberromantik."

${ }_{49}$ "[S]chon etwas von der Zivilisation angekränkelt."

${ }^{50}$ For the history of Montenegro, see Treadway and Destani.

${ }^{51}$ Hinauf in das meistverleumdete Land Europas! Man kommt leicht hinauf, sehr schwer aber ist es, auf dieser interessanten Fahrt all die Mißgunst und Vorurteile, die gehässigen Beeinflussungsversuche niederzuzwingen, deren sich ein Montenegro-Fahrer kaum erwehren kann, wenn die Absicht des Besuches bekannt geworden ist. In erstaunlicher Vielfältigkeit tritt das Übelwollen gegen Montenegro auf, es wird das interessante und arme Land von Personen verleumdet, denen eine unschöne Handlungsweise gar nicht zuzutrauen wäre. [...] Die ärgsten 
Verleumder wohnen merkwürdigerweise ziemlich weit vom verlästerten Lande entfernt; in der nächsten Nachbarschaft Mißgunst und $\mathrm{Haß}$ anzutreffen, würde begreiflich erscheinen, doch ist dies nicht der Fall!

${ }^{52}$ See Treadway $135 \mathrm{ff}$.

Ursula Reber (1972) studied Classics, German philology, philosophy, comparative religious studies and Indology at the Philipps-University in Marburg. In 1999/200o she was a DAAD-lecturer at the German department of the Tartu University, Estonia. She is currently writing her doctoral thesis on a theory of 'Metamorphoses' and is part of the internet project in Central European Studies "Kakanien revisited" (editing \& organization). Her research interests include literary theory, narratology, postcolonial studies and 19th century philosophy.

Contact: usha.reber@kakanien.ac.at 